\title{
Extraordinary incidence of cervical ribs indicates vulnerable condition in Late Pleistocene mammoths
}

The number of cervical vertebrae in mammals is highly conserved at seven. We have shown that changes of this number are selected against due to a coupling with major congenital abnormalities (pleiotropic effects). Here we show that the incidence of abnormal cervical vertebral numbers in Late Pleistocene mammoths from the North Sea is high (33.3\%) and approximately 10 times higher than that of extant elephants (3.6\%). Abnormal numbers were due to the presence of large cervical ribs on the seventh vertebra, which we deduced from the presence of rib articulation facets on sixth (posterior side) and seventh (anterior side) cervical vertebrae. The incidence of abnormal cervical vertebral numbers in mammoths appears to be much higher than in other mammalian species, apart from exceptional sloths, manatees and dugongs and indicates a vulnerable condition. We argue that the increased incidence of cervical ribs in mammoths is probably caused by inbreeding and adverse conditions that impact early pregnancies in declining populations close to extinction in the Late Pleistocene. 
2 Jelle W.F. Reumer ${ }^{1}$, Clara M.A. ten Broek ${ }^{2,3}$, Frietson Galis ${ }^{2 *}$

3 1. Natural History Museum, Rotterdam, the Netherlands \& Faculty of Geosciences, Utrecht $4 \quad$ University, Utrecht, the Netherlands

5 2. Naturalis Biodiversity Centre, Leiden, the Netherlands

6 3. University Antwerp, Evolutionary Ecology Group, Antwerp, Belgium

$7 \quad *$ Corresponding author 


\section{Introduction}

9 The number of cervical vertebrae in mammals is remarkably constant at seven. In other tetrapods,

10 the number of cervical vertebrae varies considerably, and in mammals the number of vertebrae in

11 more caudal vertebral regions is variable as well (Leboucq 1896Schultz 1961; Starck 1979;

12 Narita \& Kuratani 2005). Only manatees (Trichechus, Sirenia) and sloths (Bradypus and

13 Choloepus, Xenarthra) have an exceptional number of cervical vertebrae (Bateson 1894; Starck

14 1979; Varela-Lasheras et al. 2011). Despite the extreme evolutionary conservation of the number

15 of cervical vertebrae, intraspecific variation is not uncommon in mammals. The most common

16 variation is represented by ribs on the seventh vertebra, so-called cervical ribs, which can be

17 considered a partial or complete homeotic transformation of a cervical into a thoracic vertebra

18 (involving a change in the activity of Hox genes (Galis 1999; Li \& Shiota 2000; Varela-Lasheras

19 et al. 2011; Wéry et al. 2003)). The strong conservation of the number of cervical vertebrae

20 implies that there must be selection against intraspecific variation of this number. Indeed, very

21 strong selection against cervical ribs was shown to exist in humans (Galis 1999; Galis et al. 2006;

22 Furtado et al. 2011; ten Broek et al. 2012). Approximately 90 percent of individuals possessing a

23 cervical rib die before reaching reproductive age (Galis et al. 2006). The severe selection is due to

24 the strong association of cervical ribs with multiple and major congenital abnormalities. In other

25 mammalian species, we have also found an association with abnormalities (Varela-Lasheras et al.

26 2011). A cervical rib itself is relatively harmless, but its development is induced by a (genetic or

27 environmental) disturbance of early embryogenesis (Li \& Shiota 2000; Wéry et al. 2003;

28 Chernoff \& Rogers 2004; Galis et al. 2006;). Such a disturbance usually has multiple effects, due

29 to the highly interactive nature of early embryogenesis. Hence, the strong selection against

30 cervical ribs is indirect and due to the severity of the associated medical problems (Galis et al.

31 2006; ten Broek et al. 2012).

32 Of three caudal cervical vertebrae from Mammuthus primigenius, a sixth (C6) and two seventh

33 (C7), that were recently found in the North Sea, during infrastructural works for an extension of

34 the Rotterdam Harbour (Maasvlakte 2) and donated to the Natural History Museum in Rotterdam,

35 two possessed articulation facets for cervical ribs (the C6 and one of the C7). This surprising

36 finding aroused our interest, and we searched the extensive collection of Late Pleistocene $M$.

37 primigenius material in the Naturalis Biodiversity Centre (Leiden) to make an estimate of the 
38 incidence of this developmental abnormality. Additionally, we determined for comparison the

39 incidence of cervical ribs in skeletons of the most closely related extant species, the Asian and

40 African elephants (Elephas maximus and Loxodonta africana).

\section{Methods}

42 Specimens.

43 We analyzed 6 sixth cervical vertebrae (C6) and 10 seventh cervical vertebrae (C7) of Late

44 Pleistocene mammoths (M. primigenius), from two collections: the Natural History Museum

45 Rotterdam (NMR, table 1) and Naturalis Biodiversity Center (Naturalis, table 1). The cervical

46 vertebrae were identified as C6 and C7 based on the relative size of the spinous processes and

47 anterior tubercles. We analysed 28 specimens of extant elephants, 21 E. maximus and 7 L.

48 africana, from 5 collections: the Natural History Museum of Denmark, Copenhagen (ZMUC),

49 Naturhistorisches Museum Wien, Vienna (NHMW), The University of Vienna, the Swedish

50 Museum of Natural History, Stockholm (NRM) and Naturalis Biodiversity Center (Naturalis).

51 All mammoth specimens (see table 1 for collection numbers) are of Late Pleistocene age and 52 originate from the North Sea. Two specimens (C6, inv.nr. NMR999100006627 and C7, inv. nr. 53 NMR999100007602) were recently found during infrastructural works in the Rotterdam harbor 54 area ("Maasvlakte 2") on the North Sea seabed (Maasvlakte Zandwingebied, i.e. the source area 55 for sand extraction, c. $51^{\circ} 59^{\prime} \mathrm{N} / 3^{\circ} 53^{\prime} \mathrm{E}$ ) and allocated to the NMR by the Rotterdam Port 56 Authorities.

57 Cervical ribs.

58 We analyzed the C6 and C7 vertebrae for the presence or absence of articulation facets of cervical 59 ribs. The presence of cervical ribs can be deduced from articulation facets on the anterior side of $60 \mathrm{C7}$ (Fig. 1A and D) and, if the cervical ribs are large enough, on the posterior side of C6, as well 61 (Fig. 1B and C).

62 Statistical tests.

63 To compare the prevalence of cervical rib facets between mammoths and elephants we used a G64 test of independence, which is particularly appropriate for variable samples sizes as is often the 65 case with paleopathological data (Farke 2007). Furthermore we also used Barnard's test for $2 \times 2$ 
tables, which is appropriate for small sample sizes and yields greater power than Fisher's exact test (Barnard 1945). P-values $<0.05$ were considered as significant. All analyses were carried out in R.

\section{Results}

Articulation facets for cervical ribs on cervical vertebrae are characterized by the following combination of characteristics: (i) they have a smooth, polished-looking surface, visibly smoother than the (surrounding) cortical surface of the vertebrae; (ii) the surfaces have no vascular or nervous foramina; and (iii) the facets are bordered by a clear edge, distinguishing them from the surrounding cortex.

We found one $\mathrm{C} 7$ with a unilateral sinistral anterior rib facet indicating a left cervical rib (Fig. 1A). Five C7 did not have rib facets anteriorly and four could not be judged due to the absence of the relevant part of the vertebra. We found two C6 with rib facets on the posterior side indicating cervical ribs: one on the right side and one on the left side (Figs. $1 \mathrm{~B}$ and $\mathrm{C}$ respectively). We found one $\mathrm{C} 6$ without rib facets posteriorly and three that could not be judged. Thus, out of the nine $\mathrm{C} 6$ and $\mathrm{C} 7$ that could be evaluated, three indicate the presence of a cervical rib, i.e. an incidence of cervical rib facets of $33.3 \%$. We found in one of the $21 E$. maximus a minute cervical rib facet on $\mathrm{C} 7$ (Fig. 1d, 4.8\%) and no articulation facet visible posteriorly on C6 of the same individual. None of the seven L. africana individuals had cervical rib facets, nor were rudimentary cervical ribs found. The overall incidence of cervical ribs in the two species is, thus, $3.6 \%$. This is significantly lower than the $33.3 \%$ in mammoths, if we only consider vertebrae that can be evaluated for cervical rib articulation facets (G-test for independence, $\mathrm{p}=0.035$, Barnard's exact test, $\mathrm{p}=0.031$ ).

\section{Discussion}

The incidence of cervical rib facets in our set of Late Pleistocene M. primigenius recovered from the North Sea is extremely high ( 3 out of 9,33.3\%), almost ten times higher than that of extant elephants ( 1 out of 29, 3.6\%). In humans, an incidence higher than $1 \%$ has only been found in hospitals or isolated populations (Galis et al. 2006). An incidence higher than $25 \%$ hase only been found in children with leukemia, brain tumours and neuroblastoma (Schumacher et al. 1992; Galis \& Metz 2003; Merks et al. 2005) and in deceased fetuses and infants (Galis et al. 2006; Furtado et al. 2011; ten Broek et al. 2012). Along with the high incidence of cervical ribs in 
mammoths, the size of the articulation facets is particularly large (Figs. 1A-C), substantially larger than the articulation facet found in the one E. maximus (Fig. 1D) and, pointing to substantially larger cervical ribs than usually found in humans (see (Bots et al. 2011; ten Broek et al. 2012) for examples). Size of cervical ribs was found tobe negatively correlated with fitness in transgenic mice (Jeannotte et al. 1993; see also Bots et al. 2011;).

The exceptionally high incidence of large cervical ribs in our set of Late Pleistocene mammoths can be due to two factors. Firstly, it can be due to a high rate of inbreeding in declining populations, before final extinction. A high incidence of cervical ribs $(7.46 \%)$ has been observed in an isolated human population (Palma \& Carini 1990) in Sicily, in inbred pedigreed dogs (11.4\% (Breit \& Kunzel 1998)) and inbred minipigs (11\% at birth (Jørgensen 1998)). Generally, in inbred mammals there is an increased incidence of congenital anomalies (Cristescu et al. 2009; Räikkönen et al. 2013). Recent studies have shown that the genetic diversity was extremely low in Late Pleistocene mammoth populations in Siberia (Miller et al. 2008; Nyström et al. 2012). Additionally, the increased incidence of cervical ribs may be due to harsh conditions that impact early pregnancies, because diseases, famine, cold and other stressors can lead to disturbances of early organogenesis, that can result in the induction of cervical ribs (e.g. (Sawin 1937; Li \& Shiota 2000; Wéry et al. 2003; Chernoff \& Rogers 2004; Steigenga et al. 2006;)). Harsh conditions during the Late Pleistocene, a period of intene climatic fluctuations and ecosystem instability, are plausible (Brace et al. 2012). Furthermore, bone dystrophy in mammoth calves of Northern Eurasian Late Pleistocene populations is found regularly and assumed to be caused by mineral deficiencies in pregnant females (Leshchinskiy 2012). Hence, a combination of inbreeding and harsh conditions may be the most likely explanation for the extremely high incidence of cervical ribs. Our results, thus, are in agreement with inbreeding in populations in North-Western Eurasia, just as has been found for Siberian populations (Miller et al. 2008; Nyström et al. 2012). Finally, the high incidence and large size of the cervical ribs indicates a strong vulnerability, given the association of cervical ribs with diseases and congenital abnormalities in mammals. The vulnerable condition may well have contributed to the eventual extinction of the woolly mammoths.

\section{Acknowledgements}


127 We thank Mogens Andersen, Alex Bibl, Daniela Kalthoff, Steven van der Mije and Reinier van

128 Zelst for making specimens available and Alexandra van der Geer, Jacques van Alphen, Russell

129 Lande, Natasja den Ouden and Rienk de Jong for comments. We thank Joris van Alphen for

130 making the photographs of Figs. 1A-C.

131 References

132 Barnard G. 1945. A new test for 2× 2 tables. Nature 156:783-784.

133 Bateson W. 1894. Materials for the study of variation. London: MacMillan.

134 Bots J, Wijnaendts LC, Delen S, Van Dongen S, Heikinheimo K, Galis F. 2011. Analysis of

135

136

137

138

139

140

141

142

143

144

145

146

147

148 cervical ribs in a series of human fetuses. Journal of Anatomy 219:403-409.

Brace S, Palkopoulou E, Dalén L, Lister AM, Miller R, Otte M, Germonpré M, Blockley SP, Stewart JR, Barnes I. 2012. Serial population extinctions in a small mammal indicate Late Pleistocene ecosystem instability. Proceedings of the National Academy of Sciences 109:20532-20536.

Breit S, Kunzel W. 1998. Osteologische Besonderheiten an Wirbelsaulen von Rassehunden: eine rontgenologische und morphologische Studie. Wiener Tierarztliche Monatsschrift 85:340350.

Chernoff N, Rogers JM. 2004. Supernumerary ribs in developmental toxicity bioassays and in human populations: incidence and biological significance. Journal of Toxicology and Environmental Health, Part B 7:437-449.

Cristescu R, Cahill V, Sherwin WB, Handasyde K, Carlyon K, Whisson D, Herbert CA, Carlsson BLJ, Wilton AN, Cooper DW. 2009. Inbreeding and testicular abnormalities in a bottlenecked population of koalas (Phascolarctos cinereus). Wildlife Research 36:299308.

Farke, A. A. 2007. Reexamination of paleopathology in plesiosaurs. Journal of Vertebrate Paleontology 27:724-726

Furtado LV, Thaker HM, Erickson LK, Shirts BH, Opitz JM. 2011. Cervical ribs are more prevalent in stillborn fetuses than in live-born infants and are strongly associated with fetal aneuploidy. Pediatric and Developmental Pathology 14:431-437.

Galis F. 1999. Why do almost all mammals have seven cervical vertebrae? Developmental constraints, Hox genes, and cancer. Journal of Experimental Zoology 285:19-26.

Galis F, Metz JA. 2003. Anti-cancer selection as a source of developmental and evolutionary constraints. BioEssays 25:1035-1039.

Galis F, Van Dooren TJ, Feuth JD, Metz JA, Witkam A, Ruinard S, Steigenga MJ, Wijnaendts LC. 2006. Extreme selection in humans against homeotic transformations of cervical vertebrae. Evolution 60:2643-2654.

Jeannotte L, Lemieux M, Charron J, Poirier F, Robertson E. 1993. Specification of axial identity in the mouse: role of the Hoxa-5 (Hox1. 3) gene. Genes \& Development 7:2085-2096.

Jørgensen KD. 1998. Minipig in reproduction toxicology. Scandinavian Journal of Laboratory Animal Science 25:63-75.

Leboucq HLF. 1896. Recherches sur les variations anatomiques de la première côte chez l'homme, par H. Leboucq: Hayez.

Leshchinskiy SV. 2012. Paleoecological investigation of mammoth remains from the Kraków Spadzista Street (B) site. Quaternary International 276-277:155-169. 
170
Li ZL, Shiota K. 2000. Stage-specific homeotic vertebral transformations in mouse fetuses induced by maternal hyperthermia during somitogenesis. Developmental Dynamics 216:336-348.

Merks JH, Smets AM, Van Rijn RR, Kobes J, Caron HN, Maas M, Hennekam RC. 2005. Prevalence of rib anomalies in normal Caucasian children and childhood cancer patients. European Journal of Medical Genetics 48:113-129.

Miller W, Drautz DI, Ratan A, Pusey B, Qi J, Lesk AM, Tomsho LP, Packard MD, Zhao F, Sher A. 2008. Sequencing the nuclear genome of the extinct woolly mammoth. Nature 456:387-390.

Narita Y, Kuratani S. 2005. Evolution of the vertebral formulae in mammals: a perspective on developmental constraints. Journal of Experimental Zoology Part B 304:91-106.

Nyström V, Humphrey J, Skoglund P, McKeown NJ, Vartanyan S, Shaw PW, Lidén K, Jakobsson M, Barnes I, Angerbjörn A. 2012. Microsatellite genotyping reveals end-Pleistocene decline in mammoth autosomal genetic variation. Molecular Ecology 21:3391-3402.

Palma A, and Carini F. 1990. Variazioni dellápofisi trasversa della settima vertebra cervicale: studio anatomo-radiologico su una popolazione "segregate". Archivio Italiano di Anatomia e di Embrioligia 95:11-16.

Räikkönen J, Vucetich JA, Vucetich LM, Peterson RO, Nelson MP. 2013. What the Inbred Scandinavian Wolf Population Tells Us about the Nature of Conservation. PloS one 8:e67218.

Sawin PB. 1937. Preliminary studies of hereditary variation in the axial skeleton of the rabbit. The Anatomical Record 69:407-428.

Schultz AH. 1961. Vertebral column and thorax. Basel: S Karger Ag.

Schumacher R, Mai A, Gutjahr P. 1992. Association of rib anomalies and malignancy in childhood. European Journal of Pediatrics 151:432-434.

Starck D. 1979. Vergleichende Anatomie der Wirbeltiere. Berlin: Springer Verlag.

Steigenga MJ, Helmerhorst FM, De Koning J. 2006. Evolutionary conserved structures as indicators of medical risks: increased incidence of cervical ribs after ovarian hyperstimulation in mice Animal Biology 56:63-68.

ten Broek CMA, Bakker AJ, Varela-Lasheras I, Bugiani M, Van Dongen S, Galis F. 2012. EvoDevo of the Human Vertebral Column: On Homeotic Transformations, Pathologies and Prenatal Selection. Evolutionary Biology 39:456-471.

Varela-Lasheras I, Bakker AJ, van der Mije S, van Alphen J, Galis F. 2011. Breaking evolutionary and pleiotropic constraints in mammals: On sloths, manatees and homeotic mutations. EvoDevo 2:11.

Wéry N, Narotsky MG, Pacico N, Kavlock RJ, Picard JJ, Gofflot F. 2003. Defects in cervical vertebrae in boric acid-exposed rat embryos are associated with anterior shifts of hox gene expression domains. Birth Defects Research Part A: Clinical and Molecular Teratology 67:59-67. 


\section{Table 1 (on next page)}

List of investigated specimens and scores of articulation facets of cervical ribs.

The presence of articulation facets of ribs was indicated posteriorly on the sixth cervical vertebra (C6) and/or anteriorly on the seventh cervical vertebra (C7). Abbreviations: Naturalis - Naturalis Biodiversity Center Leiden, NRM - Naturhistoriska Riksmuseet Stockholm, NMW Naturhistorisches Museum Wien, UAV - University Anatomy Vienna, ZMUC - Zoologisk Museum University Copenhagen, RMCA - Royal Museum Central Africa Tervuren 


\begin{tabular}{|c|c|c|c|c|c|}
\hline Genus species & Institute & Collection No. & Sex & Vertebra & rib facets \\
\hline \multirow{16}{*}{ Mammuthus primigenius } & \multirow{13}{*}{ Naturalis } & RGM592809 & n.a. & $\mathrm{C7}$ & 0 \\
\hline & & RGM103337 & n.a. & $\mathrm{C7}$ & n.a. \\
\hline & & RGM132902 & n.a. & $\mathrm{C7}$ & 0 \\
\hline & & RGM139079 & n.a. & $\mathrm{C7}$ & 0 \\
\hline & & RGM172327 & n.a. & $\mathrm{C7}$ & n.a. \\
\hline & & RGM20026 & n.a. & $\mathrm{C7}$ & n.a. \\
\hline & & RGM20313 & n.a. & C6 & n.a. \\
\hline & & RGM369465 & n.a. & $\mathrm{C} 6$ & n.a. \\
\hline & & RGM40098 & n.a. & $\mathrm{C6}$ & 0 \\
\hline & & RGM40120 & n.a. & $\mathrm{C7}$ & 0 \\
\hline & & RGM4445989 & n.a. & $\mathrm{C7}$ & n.a. \\
\hline & & RGM79245 & n.a. & $\mathrm{C6}$ & n.a. \\
\hline & & RGM146248 & n.a. & $\mathrm{C} 6$ & 1 (left) \\
\hline & \multirow{3}{*}{ NMR } & NMR999100007602 & n.a. & $\mathrm{C7}$ & 1 (left) \\
\hline & & NMR999100006627 & n.a. & $\mathrm{C} 6$ & 1 (right) \\
\hline & & NMR999100007479 & n.a. & $\mathrm{C7}$ & 0 \\
\hline \multirow{21}{*}{ Elephas maximus } & \multirow{7}{*}{ Naturalis } & RMNH.MAM.46016 & n.a. & $\mathrm{C} 6, \mathrm{C7}$ & 0 \\
\hline & & RMNH.MAM.46024 & $\mathrm{M}$ & $\mathrm{C6}, \mathrm{C7}$ & 0 \\
\hline & & RMNH.MAM.39235 & $\mathrm{F}$ & $\mathrm{C} 6, \mathrm{C7}$ & 0 \\
\hline & & RMNH.MAM.39234 & n.a. & $\mathrm{C} 6, \mathrm{C7}$ & 0 \\
\hline & & ZMA 13483 & n.a. & $\mathrm{C} 6, \mathrm{C7}$ & 0 \\
\hline & & RMNH.MAM.46018 & n.a. & $\mathrm{C} 6, \mathrm{C7}$ & 0 \\
\hline & & ZMA.MAM.30069 & $M$ & C6, C7 & 0 \\
\hline & \multirow{4}{*}{ NRM } & A609596*) & $\mathrm{F}$ & $\mathrm{C} 6, \mathrm{C7}$ & 0 \\
\hline & & A591540 & n.a. & C6, C7 & 0 \\
\hline & & A600572 & n.a. & $\mathrm{C} 6, \mathrm{C7}$ & 0 \\
\hline & & A589489*) & $\mathrm{F}$ & $\mathrm{C} 6, \mathrm{C} 7$ & 0 \\
\hline & \multirow{2}{*}{ NMW } & 16545 & n.a. & $\mathrm{C} 6, \mathrm{C7}$ & 0 \\
\hline & & $5505 *)$ & $M$ & $\mathrm{C} 6, \mathrm{C7}$ & 0 \\
\hline & UAV & n.a. & n.a. & C6, C7 & 0 \\
\hline & \multirow{7}{*}{ ZMUC } & ZMUC CN2 & $\mathrm{F}$ & $\mathrm{C} 6, \mathrm{C} 7$ & 0 \\
\hline & & ZMUC CN4196*) & n.a. & $\mathrm{C} 6, \mathrm{C7}$ & 0 \\
\hline & & ZMUC CN1399*) & $\mathrm{F}$ & $\mathrm{C} 6, \mathrm{C7}$ & 0 \\
\hline & & ZMUC CN1 & $\mathrm{M}$ & $\mathrm{C} 6, \mathrm{C7}$ & 0 \\
\hline & & ZMUC CN2293*) & $M$ & $\mathrm{C6}, \mathrm{C7}$ & 0 \\
\hline & & ZMUC CN639*) & $\mathrm{F}$ & $\mathrm{C} 6, \mathrm{C7}$ & 1 (right, C7) \\
\hline & & ZMUC CN 558*) & $\mathrm{M}$ & $\mathrm{C} 6, \mathrm{C7}$ & 0 \\
\hline \multirow{7}{*}{ Loxodonta africana } & Naturalis & RMNH.MAM.45488 & $\mathrm{M}$ & $\mathrm{C} 6, \mathrm{C7}$ & 0 \\
\hline & \multirow{2}{*}{ NRM } & A601286 & $M$ & C6, C7 & 0 \\
\hline & & A600551 & $M$ & $\mathrm{C} 6, \mathrm{C7}$ & 0 \\
\hline & NMW & $\left.287^{*}\right)$ (exhibition) & n.a. & $\mathrm{C} 6, \mathrm{C7}$ & 0 \\
\hline & RMCA & RMCA 4559 & n.a. & $\mathrm{C} 6, \mathrm{C} 7$ & 0 \\
\hline & \multirow{2}{*}{ ZMUC } & ZMUC CN708*) & $\mathrm{M}$ & $\mathrm{C} 6, \mathrm{C7}$ & 0 \\
\hline & & ZMUC CN3684*) & $M$ & C6, C7 & 0 \\
\hline
\end{tabular}

PeerJ reviewing PDF |(v2014:01:1440:1:0:NEW 27 Feb 2014) 


\section{Figure 1}

Presence of rib articulation facets on cervical vertebrae of woolly mammoths (A-C) and Asian elephant (D).

Figure 1A) Posterior view of a $\mathrm{C} 6$ of a Mammuthus primigenius from the North Sea (NMR999100006627), showing an articulation facet of a cervical rib on the right side. B) Anterior view of a C7 of a Mammuthus primigenius from the North Sea ( NMR999100007602), showing a sinistral articulation facet (lower right in the picture). B) C) Posterior view of a C6 of a Mammuthus primigenius from the North Sea (Naturalis St 146248), showing an articulation facet of a cervical rib on the right side. D) Anterior view of a C7 of an Elephas maximus (ZMUC CN639), showing a minute articulation facet of a cervical rib on the right side (see inset for articulation facet). The size of cervical ribs is presumably associated with the strength of associated abnormalities. Arrows indicate articulation facets. 

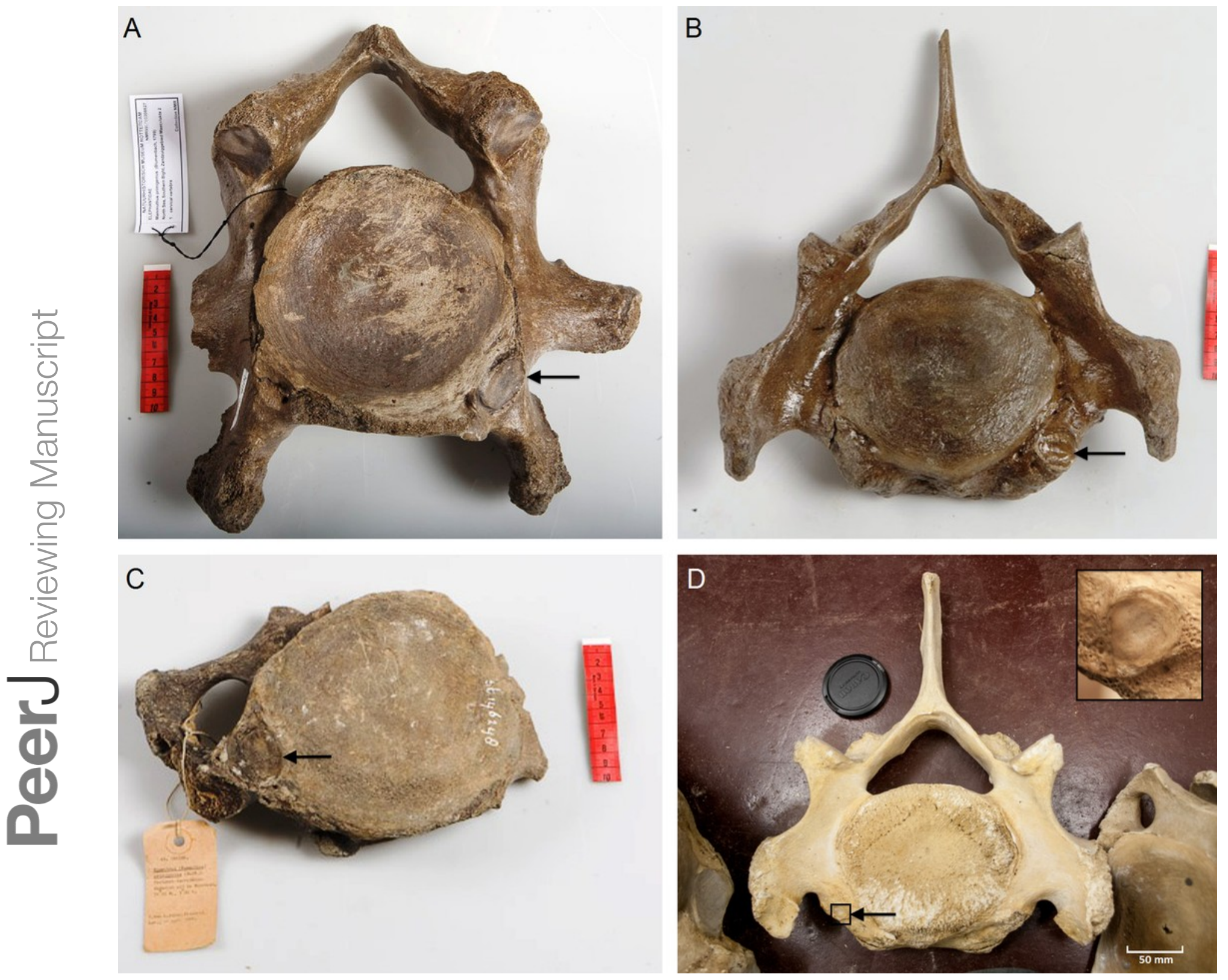